\title{
ДЕЯТЕЛЬНОСТНЫЙ ПОДХОД - ПРАКТИКО-ОРИЕНТИРОВАННАЯ ТАКТИКА ПОДГОТОВКИ БУДУЩИХ ПЕДАГОГОВ
}

\author{
Айтпаева А. К., к.п.н., доиент, чл. корреспондент МАНПО РФ, \\ Казахский национальный педагогический университет имени Абая, г. Алматы.
}

DOI: https://doi.org/10.31435/rsglobal_conf/25032021/7464

Abstract. The dynamic nature of the changes taking place in all spheres of modern society puts forward fundamentally new requirements for the professional training of specialists. Today, we need a specialist who not only has a certain amount of knowledge and skills, but is able to quickly navigate and rebuild their activities in constantly changing conditions, competitive, mobile, and ready for constant self-improvement. The training of such a specialist is possible only if there are certain conditions in the educational process to ensure the quality of training, one of which is the level of professional competence of the teacher organizing the training process.

Keywords: teacher education, bachelor's degree, network interaction, academic mobility, modular training, training module, practice-oriented training.

Динамичность развития современного общества обуславливает изменение условий во многих сферах нашей жизни, в том числе и в сфере профессиональной. Социальноэкономическая ситуация в Казахстане претерпела большие изменения, повлекшие за собой изменения и к требованиям подготовки специалистов. В период современных рыночных отношений, для того чтобы стать конкурентоспособным иметь ряд действительных умений и навыков, позволяющих осуществлять непрерывное саморазвитие, как в профессиональном плане, так и в личностном. Ведь сегодня для того, чтобы сохранить свой социальный статус, человек должен постоянно развиваться и чему-то учиться. А если говорить о профессиональном и карьерном росте, то навыки должны быть сформированы на очень высоком уровне. Сегодня в первую очередь ценится образованность, инициативность, творческий потенциал, специалист, подготовленный таким образом, будет наиболее конкурентоспособен [1].

Проведенные в области образования реформы многоаспектны. Они предусматривают структурную перестройку всей системы, обновление всех ее звеньев, модернизацию содержания и технологии педагогического процесса, установление новых форм связи между образованием и реальной жизнью, обновление системы подготовки и переподготовки педагогических кадров. Один из подходов к обновлению подготовки педагогических кадров- в сознании того, что только творческая работающий, ищущий, экспериментирующий педагог может продуктивно работать в данной системе. Это связано с коренными изменениями основанных парадигм образования.

В качестве из важнейших условий обновления образовательного процесса, стратегия модернизации образования в Казахстане выдвигает компетентностный подход. Под компетентностью мы понимаем не только профессиональную компетентность то есть «готовность к выполнению той или иной социальной роли», но и компетентность личностную«способность личности принимать решения, нести ответственность за их реализацию, справляться с тем или иным типом задач» [2].

Но при всем стремлении творчески реализовать и модернизировать образование, нередко остается без внимания тот факт, что образование является не только этапом в усовершенствовании личности, но и одним из главных компонентов культуры человека в целом. Именно в человеке предоставлено соединение образования и культуры. В разные времена развития общества выдвигались и различные требования к образованию. Получалось, что необходимость в специалистах владеющих определенным набором знаний затмевало развитие таких качеств, как готовность к самообразованию, инициативности, самодеятельности, толерантности. При всем желании дать возможность личности развить в себе творческие способности, образование ограничивалось узко профильным набором общеобразовательных предметов.

Данилов Д.А. отмечает, что среди образовательных парадигм, определяющих функционирование и развитие образовательной среды современных условиях следует выделить 
раскрытие, формирование, развитие и актуализацию неповторимой индивидуальности каждого отдельного человека. Это определяет необходимость создания в образовательном учреждении совершенно новой ситуации, которая раньше исходила из того, что они дают знание, другие усваивают его, одни ответственны за организуемый процесс, другие- исполнители и т.д. А современная ситуация исходит из уникальности не только одаренных, интеллектуально развитых, но и каждой личности. Уникальность и неповторимость каждой личности может увидеть, найти, развивать только такой специалист, который обладает развитым личностнопрофессиональным потенциалом, богатым педагогическим чутьем, находится в постоянном поиске нового передового. Речь идет о педагогике нового поколения, профессионализм которого характеризуется его многосторонней подготовленностью, где особое место занимают его качества компетентностного наставника растущего человека [3].

Значительное расширение функций педагога в современных условиях, требует от него постоянного пополнения знаний и умений общекультурного и профессионального характера, определенной самоотверженности, высокой ответственности за свои профессиональные действия. Для формирования этих качеств нужны новые подходы к профессиональной подготовке в педагогическом вузе.

Проблема совершенствования профессиональной подготовки учителей всегда занимала определенное место в фундаментальных и прикладных исследованиях специалистов. Среди них можно выделить труды Хмель Н.Д., в которых она обосновала технологию целостного педагогического процесса и акцентировала, что в процессе профессиональной подготовки необходимо опираться на три составляющих профессиональной готовности - личностную, содержательную и процессуальную [4].

В работах В.А. Кан-Калика разрабатывалась система интенсивного психологопедагогического обучения, выделены принципы интенсификации подготовки учителяиндивидуально-личностный подход к выявлению, формированию и развитию творческой педагогической индивидуальности; профессионально -деятельностный подход к процессу становления творческой педагогической индивидуальности, формированию педагогической направленности личности [5].

В этих и других психолого-педагогических исследованиях признается, что в современном образовании лидирующим является деятельностный подход. Хотя в теории и практике профессионального образования до недавнего времени деятельностный подход фактически не рассматривался как особый методологический концепт в силу того, что подготовка профессиональных кадров в целом имеет деятельностную направленность, и все образовательные технологии и модели, разрабатываемые в рамках этой образовательной отрасли, в той или иной мере могут рассматриваться как реализация деятельностного подхода. Однако в настоящее время его концептуальная проработка приобретает все большее значение (А.А. Арламов, Н.Ф. Талызина) и др.).

Суть деятельностного подхода выражается в направленности всех педагогических средств, технологий, условий на организацию интенсивной, постоянно усложняющейся деятельности, содержащей новые для развивающейся личности элементы, обеспечивающие решение определенных жизненно важных задач. Существенные характеристики деятельности обеспечивают перевод студента в позицию субъекта, инициируют его активное отношение к окружающей действительности, посредством которого обучаемый осваивает мир, науку и культуру, способы познания и преобразования социума, формирует и совершенствует личностные качества [6].

Деятельность является фактором развития духовного мира, формой и условием реализации культурных потребностей человека, это сфера реализации человеком своего личностного потенциала достижения жизненных целей, успехов. Деятельность служит источником и критерием научного познания, самопознания и саморазвития, создает условия для самореализации человека в системе общественных отношений, для реализации его социальных интересов: обеспечивает познание и преобразование окружающего мира. Поэтому использование в профессиональной подготовке студента деятельностного подхода на наш взгляд правомерно. Основы деятельностного подхода в психологии были заложены Л.С. Выготским, А.Н. Леонтьевым, рассматривающими деятельность как процесс, в результате которого формируется психика человека. Последующие исследования показали 
неправомерность выделения деятельности в качестве единственного освоения и источника развития человеческой психики. Л.С. Рубенштейн показал, что любые внешние причины, в том числе деятельность действуют на человека не непосредственно, а преломляясь через внутренние условия. Психика человека исключительно избирательна.

С позиций гуманистической психологии развитие личности имеет свои внутренние закономерности, внутреннюю логику, не являясь пассивным отражением действительности, в условиях которой оно осуществляется. «Понятие внутренней логики развития, являющееся ключевым для гуманистической психологии, фиксирует то обстоятельство, что человек, выступая ключевым для гуманистической психологии, фиксирует то обстоятельство, что человек, выступая саморегулирующимся субъектом, в процессе своей жизни деятельности приобретает такие свойства, которые не предопределены однозначно ни внешними обстоятельствами, в том числе внешней деятельностью, ни внутренними условиями, в том числе внутренней деятельностью» [7; 88].

Реализация деятельностного подхода подразумевает организацию образовательного процесса как единства разных видов деятельности студентов (учебной, учебнопрофессиональной, научно-исследовательской, вне учебной, социокультурной и др.), целесообразно организованных и педагогически скоординированных для достижения цели профессиональной подготовки.

Деятельностный подход обеспечивает переход от концепции «передачи готовых знаний» к концепции «образование-становление». Очевидно, что реализовывать новые цели образования невозможно, если студент пассивно усваивает готовые истины. Необходим его самостоятельный поиск, в процессе которого как раз приобретается опыт общения, целеполагание, достижения поставленных целей, опыт рефлексивной самоорганизации и самооценки - то есть формируются те «способности к самодеятельности», о которых говорил А. Дистервег.

Таким образом, деятельностных подход в обучении — это планирование и организация учебного процесса, в котором главное место отводится активной и разносторонней, в максимальной степени самостоятельной познавательной деятельности обучающихся, ориентированных на заданный результат. Таким требованиям наиболее полно соответствуют современные интерактивные образовательные технологии. Особенностью интерактивных образовательных технологий можно считать их ориентированность на разнообразное взаимодействие не только студентов с преподавателем в конкретной учебной дисциплине, но и студентов разных курсов (проектная деятельность), а также самих преподавателей (межпредметные связи).

Роль интерактивных технологий в образовательном процессе вуза заключается в развитии у студентов умений работать сообща, например, в учебных мини-проектах, во временных командах, малых группах и стремиться к качественным результатам. Интерактивные технологии позволяют студентам обогатить свой опыт через учебную деятельность те компетенции социального взаимодействия, которые затем могут оказаться необходимыми в их будущей профессиональной и социальной жизни. Основной целью интерактивных образовательных технологий является активизация коллективной деятельности всех участников образовательного процесса.

В традиционной форме проведения занятий главным действующим лицом и менеджером является преподаватель; существенное отличие интерактивной формы проведения занятий состоит в том, что процессе присутствуют две активные стороны: преподаватель и студент, то есть педагогическая деятельность есть деятельность по управлению деятельностью обучающихся и процессом взаимодействия с ними. Если в традиционная форма проведения занятий предполагает авторитарный стиль общения, то интерактивная более ориентирована на демократический стиль отношений.

Стиль взаимодействия в учебной аудитории, предложенный преподавателем, студент, став специалистом, перенесет в свою будущую профессиональную деятельность. Наконец, в традиционных технологиях личность преподавателя не учитывается: наоборот в интерактивных технологиях, личность преподавателя имеет особое значение. Позитивное отношение со стороны студентов завоевывает метод кейс-стадии. Студенты видят в нем возможность проявить инициативу, почувствовать самостоятельность в освоении теоретических положений и овладении практическими навыками. Не менее важно и то, что анализ ситуаций довольно сильно воздействует на профессионализацию студентов, способствует их взрослению, формирует интерес и позитивную мотивацию к учебе. 
Кейс-метод выступает как образ мышления преподавателя, его особая парадигма, позволяющая по-иному думать и действовать, развить творческий потенциал. Этому способствует и широкая демократизация, и модернизация учебного процесса, раскрепощение преподавателей, формирование у них прогрессивного стиля мышления, этики и мотивации педагогической деятельности. Метод кейс-стадии можно назвать методом анализа конкретных педагогических ситуаций. Суть метода довольно проста: для организации обучения используются описания конкретных ситуаций (от английского «саse-случай»). Студентам предлагается осмыслить реально жизненную ситуацию, описание которой одновременно отражает не только какую-либо практическую педагогическую проблему, но и актуализирует определенный комплекс психолого-педагогических знаний, которые необходимо усвоить при разрешении данной проблемы. При этом сама проблема не имеет однозначных решений. Особо важным является то, что действия в кейс либо даются в описании, и тогда требуется их осмыслить (последствия, эффективность), либо они должны быть предложены в качестве способа разрешения проблемы. Но в любом случае выработка модели практического действия представляется эффективным средством формирования профессиональных качеств обучаемых.

Метод кейс-стадии - это не просто методическое нововведение, распространение метода напрямую связано с изменениями в современной ситуации в образовании. Можно сказать, что метод направлен не столько на освоение конкретных знаний, или умений, сколько на развитие общего интеллектуального и коммуникативного потенциала студента и преподавателя.

Кейс-метод может стать реальным средством повышения профессиональной компетентности преподавателя, способом соединения учебного, образовательного и исследовательского содержания в обучении. Кейс-метод может стать реальным средством повышения профессиональной компетентности преподавателя, способом соединения учебного, образовательного и исследовательского содержания в обучении. Кейс-метод является достаточно эффективным средством организации обучения, однако его нельзя считать универсальным, применимым для всех дисциплин и решения всех образовательных задач. Эффективность метода в том, что он достаточно легко может быть соединен с другими методами обучения. В таблице 1. представлены возможности интеграции разных методов при организации работы с кейсом.

Таблица 1. Возможности интеграции разных методов приемов и организации работы с кейсом.

\begin{tabular}{|c|c|}
\hline Метод интегрированный в кейс-метод & Характеристика его роли в кейс-методе \\
\hline Моделирование & Построение модели ситуации \\
\hline Системный анализ & Системное представление и анализ ситуации \\
\hline Мысленный эксперимент & $\begin{array}{l}\text { Способ получения знаний о ситуации посредством } \\
\text { ее мысленного преобразования. }\end{array}$ \\
\hline Методы описания & Создание описание ситуации \\
\hline Проблемный метод & $\begin{array}{l}\text { Представление проблемы, лежащей в основе } \\
\text { ситуации }\end{array}$ \\
\hline Метод классификации & $\begin{array}{l}\text { Создание упорядоченных перечней, свойств, } \\
\text { сторон, составляющих ситуации. }\end{array}$ \\
\hline Игровые методы & $\begin{array}{l}\text { Представление вариантов поведения героев } \\
\text { ситуации }\end{array}$ \\
\hline «Мозговая атака» & Генерирование идей относительно ситуации \\
\hline Дискуссия & $\begin{array}{l}\text { Обмен взглядами по поводу проблемы и путей ее } \\
\text { решения }\end{array}$ \\
\hline
\end{tabular}

Метод кейс-стадии имеет очень широкие образовательные возможности. Многообразие результатов. Возможных при использовании метода можно разделить на две группы:

учебные результаты, как результаты, связанные с освоением знаний и навыков (освоение новой информации, методов сбора данных, анализа, умение работать с текстом, соотнесение теоретических и практических знаний);

образовательные результаты - как результаты образованные самими участниками взаимодействия, реализация личных целей обучения (создание авторского продукта, образование 
и достижение личных целей, повышение уровня профессиональной компетентности, появление опыта принятия решений, действий в новой ситуации, решения проблемы).

Таким образом, видно, что деятельностный подход к обучению повышает способность студентов к приобретению знаний, их переносу в новые условия. Происходит развитие компетенций с точки зрения результатов деятельности обучаемого. И наконец деятельностный подход способствует формированию у студентов профессионально-значимых личностных качеств, которые будут способствовать в его становлении как специалиста высокого класса, достижении высокого уровня самореализации в жизни.

\section{ЛИТЕРАТУРА}

1. Пралиев С.Ж., Жампеисова К.К., Хан Н.Н., Колумбаева Ш.Ж. Кайдарова А.Д. Концептуальные основы системной модернизации высшего педагогического образования РК: Педагогика и психология. Научно-методический журнал КазНПУ имени Абая. 2015. № 1 - С.41-57.

2. Безюлева Г.В., Иванова Н.В. Профессиональная компетентность: аспекты формирования. Методическое пособие. - М., 2015г.

3. Данилов Д.А. Концептуальные подходы к персонификации подготовки студентов к профессиональнопедагогической деятельности.// Сибирский педагогический журнал Выпуск №6., 2016г.

4. Хмель Н.Д. Теория и технология реализации целостного педагогического процесса.-Алматы.2008г.-158c.

5. Кан-Калик В.А. Учителю о педагогическом общении/ В.А.Кан-Калик.-М.:1987г.

6. Пак Л.Г. Яблонская Ю.П. Реализация деятельностног подхода в профессиональной подго овке студентов вуза // Современные проблемы науки и образования. - 2015.-№2-1:URL:http://scienceedukation.ru.article

7. Загвязинский В.И., Атаханов Р. Методология и методика психолого-педагогического исследования.: Учебное пособие для студентов высш. пед. учебн. заведений. - М.: Академия, 2015.-208c. 